\title{
Complexities of Large-Scale Technology Project Failure: A Forensic Analysis of the Seattle Popular Monorail Authority
}

\author{
Nina Yuttapongsontorn \\ The Information School \\ University of Washington \\ E-mail: nuntida@u.washington.edu \\ Kevin C. Desouza ${ }^{1}$ \\ Assistant Professor \\ The Information School \\ University of Washington \\ Mary Gates Hall, Suite 370 \\ UW Box 352840 \\ Seattle, WA 98195-2840 \\ USA \\ Phone: +1 206-616-0880 \\ E-mail: kdesouza@u.washington.edu \\ Ashley Braganza \\ Senior Lecturer \\ Cranfield School of Management \\ Cranfield University \\ Central Avenue, Building 111 \\ Cranfield, Bedfordshire \\ MK43 0AL \\ UK
}

\section{Acknowledgements}

We thank Caroline Dombrowski for her excellent research and editing assistance with this paper. Kevin Desouza acknowledges partial support from the Institute for Innovation in Information Management through the Leveraging Ideas for Organizational Innovation and the Demystifying the Link between Innovation and Business Value projects.

\footnotetext{
${ }^{1}$ Corresponding Author
} 


\section{Complexities of Large-Scale Technology Project Failure: A Forensic Analysis of the Seattle Popular Monorail Authority}

\section{Abstract}

"Being stuck in traffic doesn't have to be a way of life." This beautiful prologue came from the Elevated Transportation Company (ETC) board's letter in the ETC Seattle Popular Monorail Plan, one of the largest public works projects ever proposed in the city of Seattle. Three years after this proposal, the Seattle Monorail Project (SMP) was shut down by voters on November 8 , 2005. This paper critically analyzes the SMP through the lens of stakeholder theory. This perspective provides valuable insights into the failure of the SMP. We theorize that SMP's failure might have been avoided had its leadership recognized the many stakeholders that had power over the plan and, more importantly, the dynamic changes in relationships between the stakeholders. Failure might also have been avoided by managing conflicts in stakeholders' expectations. Specifically, we use stakeholder theory to develop four propositions that are relevant in the context of large-scale technology projects. One, organizations are more likely to succeed when have effective mechanisms for monitoring and evaluating interactions between stakeholders and changes in their positions in relation to their strategic innovation projects. Two, organizations are more likely to succeed when they tradeoff the conflicts in expectations and interests that stakeholders hold. Three, organizations are more likely to implement complex technology projects by understanding stakeholders' expectations and the interplay between stakeholders. Four, organizations are more likely to achieve their innovative projects when they define stakeholders in terms of their power over their strategic objectives. The paper makes a contribution both to the research and practice of major technological infrastructure projects, strategic innovations, and government technology management.

Keywords: Seattle Monorail Project; Technology Projects; Innovation; Stakeholder Theory; Public Policy; Innovation Policy; Government Projects 


\section{Introduction}

History shows that large scale innovative technology projects, financed with public funds, are fraught with dangers and often fail to deliver the product or the results promised at the start of the initiative (Iacovou and Dexter, 2004; Montealegre and Kiel, 2000; Collingridge and Margetts, 1994). For instance, the Las Vegas monorail system promised easy public transportation, increasing ridership and gradual expansion; instead, riders never reached high numbers (largely because of the route, lack of park and rides, and station placement) and to recover costs, officials raised the price of a ticket, causing ridership to fall even further (Schumaker, 2006). An even more costly project was the baggage handling automation at the Denver Airport, an information system and mechanical engineering innovation that flat-out failed to deliver and far exceeded budget (Johnson, 2005). When automation was dropped in favor of old-fashioned human sorting of baggage, it was estimated that over $\$ 1$ million would be saved per month (Johnson, 2005). The Denver innovation failure became part of software engineering lore as a disaster to avoid (Brooks, 1987).

Projects that do ultimately deliver their product do so with significant cost and time overruns, such as the Boston Big Dig, a project to create an underground tunnel to relieve a heavy traffic problem. The Boston Big Dig took twenty years and \$14.6 billion dollars and still has problems with leaks and faulty construction to this day (Powell, 2004). The project was originally budgeted at $\$ 2.5$ billion (Powell, 2004). Projects that have technology as the central piece are particularly prone to failure, leading some to question whether or not such projects should be started at all.

Nonetheless, there are times when large-scale infrastructure projects financed by public funds can only be done through the medium of a major project. Large-scale publicly funded infrastructure projects tend to have not only a technological dimension but also some aspect of innovation. When politicians or government officials commit tax payers' money, the results must deliver benefits to all members of the community thereby posing a requirement to address the needs of multiple stakeholder groups. The combination of technology, innovation, and multiple stakeholders, make large-scale, government-run projects complex, and hence even more prone to failure.

Prior research on the failure of large scale projects suggests that one of the main reasons such projects fail is due to poor leadership (Roepke, Agarwal, and Ferratt, 2000). CEOs often 
call into the trap of 'launch and forget' rather than 'launch and monitor' large IT-innovation projects. The underlying reasons for the failure of technology-based innovation projects often have little to do with the technology itself. Instead, factors for failure are usually associated with organizational change issues (such as poor leadership, unclear strategy, poorly communicated goals, ineffective project management, invisible sponsorship, no common language and vocabulary, loss of business engagement and inflexible structure and hierarchy) (McAfee, 2003). While many of these reasons are well researched in the literature, we believe that there are more fundamental reasons that drive failure. We argue that the roots of failure of large-scale, government-run innovative technology projects can best be explained by analysis of stakeholders.

In large-scale projects an abundance of stakeholder groups with unique needs is inevitable. Each stakeholder group might have different views of the project, its goals, its deliverables, and even its costs. Moreover, the conflicts that occur between stakeholder groups, and even within these groups, can detract attention and energy from the innovation being considered or the essence of the project. We argue that the roots of failure of large scale government run infrastructure projects are better explained by examining stakeholders. Stakeholder theory emerged from the field of strategic management as a contradistinction to economic based models of the firm such as input-output, agency and transaction cost theories (Freeman and Reed, 1983; Freeman, 1984; Friedman and Miles, 2002; Mitchell et al., 1997). These theories conceptualize the organization as a 'black box' which converts raw materials into outputs based on contracts with resource providers. The assumptions underpinning these theories include profit maximization, shareholder supremacy and constant efficiency gains. Stakeholder theory, on the other hand, argues that there are wide ranging individuals and groups that have interests in the focal organization. Consequently, organizations should consider each stakeholder group, examine their interests and respond to these interests. One of the limitations in literature is that stakeholder theory is used to study subsets of focal organizations or stakeholders. For example, Donaldson and Preston's (1995) study excludes organizations that do not have shareholders, such as public sector organizations. Rowley and Moldoveanu's (2003) study focuses exclusively on groups that might be hostile to the focal organization such as environmental activities and trade unions and precludes customers and suppliers. This paper overcomes these limitations by examining a range of stakeholders, those for and against the 
Seattle Monorail Project (SMP). Furthermore, our study broadens the discussion of stakeholders thereby extending the theory to encompass the sources of stakeholder power and their expectations.

In this paper, we present the findings of one of the biggest public sector infrastructure disasters in the history of the US: the Seattle Popular Monorail. This case arguably could feature as one of the biggest government-led disasters in the world. The proposed Seattle Popular Monorail was one of the largest public works projects ever proposed in the city of Seattle. At the time, it was lauded as a comeback of monorails and a model in how to revamp transportation systems (Scigliano, 1998). After three years of planning and research, the SMP was shut down by voters on November 8, 2005. This paper studies the history of the plan, the challenges the plan's proponents faced, criticisms and reactions, and reasons for the plan's failure.

This public sector infrastructure disaster is particularly notable because the City of Seattle has had experience in monorail projects. Seattle's original monorail was one of the world's first modern monorails, and it was the first full-scale monorail system in the US. It was built in 1962 for the Seattle Century 21 World's Fair and cost $\$ 3.5$ million. The 1.2-mile-long monorail was built in only 10 months and served as a main link between the fairgrounds and the amenities downtown. During the six months of the fair, the trains carried more than eight million guests and easily earned back its initial capital construction costs in just five months. After the fair, the monorail system was turned over to the Century 21 Corporation at no cost. Century 21 then sold the system to the City of Seattle in 1965 for $\$ 600,000$. Today, the trains carry more than 2.5 million riders each year, and it still operates at a profit after forty years of operation. While one could have hoped for a similar happy ending with the proposed Seattle Popular Monorail this was not to be.

The rest of the paper is organized as follows: We begin by outlining our research methodology and briefly introducing stakeholder theory. Next, we present the case study of the SMP. We then analyze the case study through the lens of multiple stakeholders. Following this we describe the interactions among stakeholders. We conclude the paper by developing our propositions and outlining implications of the study.

\section{Research Methodology}


In order to study the Seattle Monorail Project, we did extensive secondary research mostly by reading websites and blogs. The websites and blogs provided us with information not only from the pro-monorail viewpoint, but also from the monorail opponents' side. The website that provided us with the most relevant documented information was the Seattle Monorail Project Homepage (http://www.elevated.org). This site consists of all archived documents, and includes the original Elevated Transportation Company Monorail Plan, a news room, and car-tab tax information.

The website of the group 2045 Seattle (http://2045seattle.org) was created to support the group's mission “to break Seattle's reputation of politely standing still, of not dealing with our problems head on, transit or otherwise, while the rest of the world builds around us." It defined itself as "a group of concerned Seattle citizens with two things in common: We support the construction of the Seattle Monorail and we are the younger voices largely absent from the current debate, yet we are responsible for the project's long term impact" (2045 Seattle, 2005). The site covers all past group activities and contains archived monorail content and many links to other Seattle monorail sites. There are also areas for people to leave comments and concerns about the contents of the site.

The Friends of the Monorail website (www.monorail.org) is a site for distributing monorail-related news (including news about the original monorail) and facilitating discussions about the monorails. People can also join e-mail discussion groups and become members. This site has links to the Seattle Monorail Project homepage and other monorail sites. It does not, however, have much information about the new monorail at this time. This may be due to the fact that the project was killed on November 8, 2005.

The City of Seattle website (http://seattle.gov) is the official website for the City of Seattle. This is an essential site in researching the city's former project. We found Seattle Monorail Project milestones at this site, as well as the section "You Talk Back, We Listen," which gave us ideas about how people think about many concerns regarding city projects, including the monorail.

By gathering information from the websites above and other relevant online resources ranging from the original project proposal itself to old newspaper articles and Seattle residents' blogs, we had enough information to grasp what was going on with this project. Using the data we begin to conduct a forensic analysis to piece together a story-line that would explain the 
failure of the project. The storyline constructed also helped us draw out stakeholder groups, their contributions to the project, the interaction among the stakeholder groups, and the resultant impacts of these groups on the overall failure of the project. The storyline that began to emerge as we gathered our data was that there were several distinct groups that had an interest in SMP, which supports the findings of Rowley and Moldoveanu (2003). However, while they focused on stakeholders that would be broadly hostile to a focal organization, we discovered that interactions between the stakeholders provided deeper insights. SMP had strong support from some stakeholders and these acted in ways that promoted the development of the monorail; other stakeholders were against the monorail and they took actions to halt the development. There were other stakeholders who were neutral but could be swayed potentially to move in one direction or the other. Some stakeholders moved their position over time. From the perspective of SMP's management dealing with one group alone was simply not an option. We selected stakeholder theory as the lens through which to examine the data because it provided a suitable framework to study the range of stakeholders and their interactions.

\section{Stakeholder Theory}

The common thread that runs through all definitions of stakeholders is that stakeholders have an interest in the focal organization (Atkinson, Waterhouse, \& Wells 1997; Donaldson \& Preston 1995; Freeman 1984; Rowley \& Moldoveanu 2003). The argument that follows naturally is that because when they have something to gain or lose. The general argument that follows is that stakeholders will act for or against a focal organization depending on whether their interests are affected positively and adversely. What is problematic in the literature currently is a clear understanding of the terms 'interests' and 'stakes'. Stakeholders' interests appear in diverse forms: they have influence or can influence the focal organization (Freeman, 1984); they have power, legitimacy and urgency (Rowley, 2004); legal and moral rights (Carroll, 1993); desired end states (Frooman, 1999). Stakeholders have interests in organizations managers "should acknowledge the validity of diverse stakeholder interests and should attempt to respond to them within a mutually supportive framework" (Donaldson and Preston 1995: 87, italics in original). The assumption underpinning stakeholder theory is that individuals and groups gain a stake in a focal organization A consequence of the use of the terms interests and stake being vague is that this has led to excessively broad definitions of what might constitute stakeholders for a specific organization, exemplified by 'the local community'. 
Current definitions of stakeholder have a significant in-built reactive element. To be sure, most people and groups external to the focal organization don't know in advance what actions it is going to take; in other words, they only become aware of the action once it is announced or they experience it in some way. They then make an assessment of the action and react in a positive, negative, or neutral manner. Similarly, organizations can't know the actual impact of actions on stakeholders interests until after they have taken the action. They then have to react to any discontent caused by their action. Stakeholders can have a significant impact on an organization's strategy to introduce innovative products, which by their nature take significant time and investment to develop. The return on the investment can be hamstrung by stakeholders who take a stand against the product. Monsanto, for example, developed a range of genetically modified foods which it could not bring to market to recover its investment.

We argue therefore that an emphasis on stakeholders' interests alone is limited and can lead to confrontation between stakeholders' and the focal organization as one or the other may be surprised by the other. This does not imply that stakeholders' don't have interests or that these interests can be neglected. Instead, we want to augment prior research by suggesting stakeholders can be more precisely identified when organizations consider the power they have over whether or not specific organizational objectives can be achieved. This approach ensures organizations go beyond obvious stakeholders such as customers and shareholders; they are able to spot individuals and groups that may not be considered to be stakeholders currently. Using organizational objectives as a basis for identifying stakeholders also allows diverse stakeholders to be viewed in a similar manner. Thus, business partners, investors, customers and suppliers as external stakeholders and staff and management as internal stakeholders might all be important to an objective about innovation to a process (Greasley 2004).

While it is clearly important to understand the range of stakeholders, we argue that it is also essential to understand the interplay between the stakeholders. Much of the current literature focuses on the relationship between one or more stakeholders and the focal organization. For example, Rowley and Moldoveanu's (2003) work focuses on environmental activist groups, organized community groups and employee unions as stakeholders (p.205) but specifically leaves out customers, which for many organizations is the most important stakeholder. Customers can form a powerful group when they boycott a particular product - examples include Coke's change in the formula and Nestlé's sale of powdered baby milk in Africa. Customers, 
suppliers and regulators can be just as powerful as the stakeholders Rowley and Moldoveanu emphasize. We suggest that the relationships and interactions between stakeholders can have a bigger influence on the organization's implementation of strategy. An understanding of the dynamic changes that are taking place between stakeholders' relationships can have a significant impact on the organization.

Moreover, different stakeholders can place a variety of conflicting demands upon an organization (Meyer \& Rowan 1977). Much of the research on stakeholder theory has focused on the nature of the theory - descriptive, instrumental, normative - (Donaldson and Preston 1995), the salience of stakeholders (Mitchell et al 1997) or the drivers that induce stakeholders to take or withhold action against the organization (Post, Preston and Sachs 2002). The common theme that runs through defining stakeholders is that they have 'interests' in the organization. Interests take the form of rights that stakeholders such as employees might have, risks that stakeholders such as shareholders or suppliers take and benefits received or exchanged for example from customers. However, the use of interests as the gauge for whether or not individuals, groups or organizations should be taken seriously by a focal organization masks a more important issue. This is the conflicting demands that stakeholders place on the firm. Post et al (2002) discuss the case of Monsanto and its stakeholders. Each is positioned on a framework that is made up of three categories: resource base, industry structure and social political arena. Their framework, for example, hides the fact that while ordinary consumers have come out strongly against the proliferation of genetically modified food, other stakeholder - governments - are quite happy to support Monsanto's activities (http://www.blacklistednews.com/view.asp?ID=3249). Conflicts in stakeholders' demands lead to a number of outcomes. One, internal conflict as different divisions or departments pull in different directions at the same time, for example, the internal compliance department wanting to stick to the rules laid down by regulators and the sales and marketing department selling genetically modified products to meet sales targets laid down by senior managers and analysts. Two, resources get stretched because each division or department chases the organization's finite resources to meet the needs of the stakeholder they have the most dealings with. Three, conflicts in stakeholders expectations get resolved in a trickle down manner. For example, in one large multinational organization institutional shareholders wanted costs to decrease; customers wanted higher levels of service with no increase in prices and the board wanted customer satisfaction measures to go up. The board decided to reduce the 
headcount in the call centre to cut costs and place customer satisfaction measures on call centre staff. However, they hadn't told the remaining staff that the time spent per call should decrease. People in the call centre simply spent longer on the phone with each customer that got through because these customers then rated their satisfaction as high or very high. Over time, large numbers of customers left the organization resulting in a financial loss. Very simply, customers expect lower prices, suppliers expect higher margins, and shareholders expect higher dividends and so on. The extent to which these conflicting expectations can be managed effectively is critical to the longer-term success of any organization (Ruffini, Boer, \& van Riemsdijk 2000). Where stakeholders' expectations change in ways that require new practices and / or knowledge, an organization and specific functional communities, in particular, need to respond dynamically (Chan 1993). Functional communities may need to develop or absorb new knowledge rapidly to meet stakeholders' new or evolving expectations while concurrently maintaining or enhancing those that address stakeholders' on-going needs (Cohen \& Levinthal 1990). Changes to stakeholders' expectations can lead to tensions between the espoused practices (contained in manuals and operating procedures) and actual practices that functional communities undertake.

To summarize, this paper makes a contribution to the growing literature on stakeholder theory by examining how a wide assortment of stakeholders can play a critical role in the success of large-scale government-run technology projects. In addition, the paper will develop propositions to guide the management of stakeholders and the interactions between stakeholders.

\section{Seattle's Traffic Problem}

Traffic in Seattle is awful. The Seattle-Everett area was the second-worst congested area in the nation during 1999. The Texas Transportation Institute at Texas A\&M University found that "it took 81 percent longer to travel over freeways and major arterials during rush hour than it did during periods when traffic was free-flowing" (Foster, 2001). "The annual congestion for Seattle-Everett-area commuters added up to 53 hours in delays for the year" (Foster, 2001). Moreover, the Institute also found that the cost of congestion in lost wages and wasted fuel for the Seattle-Everett area driver in 1999 was \$427 on average. According to a Federal Highway Administration report (Federal Highway Administration Office of Operations, 2005) traffic congestion is caused by seven root factors, which often interact with each other: physical bottlenecks ("capacity"), traffic incidents, work zones, weather, traffic control devices, special events, and fluctuations in normal traffic. 
In Seattle, much traffic congestion is caused by physical bottlenecks. An outstanding example of this is the bottleneck in the main section of the Highway 520 Bridge. 115,000 vehicles travel daily on the four-lane 520 bridge across Lake Washington. This is typically a congested area, and commuters need to spare some time for a delay if they need to use the bridge. Downtown Seattle is a center of business and entertainment. Consequently, Seattleites need to be aware that every time an event occurs downtown, traffic will be worse. The climate in Seattle is also a main factor in congestion. As we all know, rain is common in Seattle. There is more congestion on a rainy day than when the weather is nice. Moreover, the rain also increases the rate of car accidents in Seattle.

The City of Seattle has considered many projects to reduce traffic congestion. Various organizations have studied these problems and have undertaken citywide planning to make Seattle more accessible. This includes:

- The Seattle Transit plan, which is the basis for transit strategies in the City's Transportation Strategic Plan;

- Sound Transit projects, which build a mass transit system connecting regional employment and population centers in King, Pierce, and Snohomish counties;

- Puget Sound Regional Council Transportation Enhancement projects, which serve as a forum for developing policies and making decisions about regional growth and transportation issues in the four-county central Puget Sound region;

- Washington State Department of Transportation projects in King County, which provide Puget Sound traffic information, operate the State Route Web Viewer (SRweb), and provide information on weather conditions;

- The Seattle Monorail Project (SMP). Building a new monorail turned out to be one of the largest transportation projects ever proposed in the city of Seattle.

Insert Table 1 Here

\section{From Start to Finish: The Seattle Monorail Project}

In this section, we trace the Seattle Monorail Project in detail from its inception to its demise. We do so to provide the contextual details to understand the complexities associated with this 
innovative public-sector technology project failure (see Table 1 for a chronology of events in the SMP).

\section{The Movement for a New Monorail - Initiatives 41 and 53}

The effort to establish a new monorail started in 1997, when Seattle activists and volunteers launched Initiative 41, proposing a 40-mile-long monorail system across the city (City of Seattle, 2006). Initiative 41 was approved by $53 \%$ of Seattle voters. This resulted in the formation of a Public Development Authority (PDA) to seek private money to develop the monorail and the Elevated Transportation Company (ETC) was created to start developing an X-shaped monorail system.

The \$200,000 Public Development Authority (PDA) funding ran out in 2000. The Seattle City Council repealed Initiative 41 and disbanded the ETC. Seattle activists and volunteers started an organization called Rise Above it All and launched Initiative 53. That same year, the second monorail initiative was approved by $56 \%$ of Seattle voters. The ETC was reinstated, and given $\$ 6$ million to generate a plan for a Seattle monorail system. The initiative provided a number of parameters for the planning work. It required that the monorail system be:

- Elevated;

- Quiet;

- Linked to the neighborhoods.

- Compatible with other kinds of transportation; and

- Extendible, throughout and further than city's limits.

Initiative 53 gave the ETC two years to finish a plan before a vote in 2002. The plan developed by ETC was called the "Citywide Monorail System." Five corridors of monorail lines would cover the Seattle area, with three of the corridors stretching north and south and two stretching east and west. Each line was named after a color. The first route to be developed would be the Green Line, which would link Downtown Seattle with West Seattle in the southwest part of the city and the Ballard and Crown Hill districts in the northwest part of the city.

\section{The Seattle Popular Monorail Authority}

In November 2002, 50.23\% of Seattle voters approved Seattle Citizen Petition No. 1. This led to the institution of a monorail authority (the Seattle Popular Monorail Authority, which would later 
be called the Seattle Monorail Project) to build, own, operate and maintain a city monorail system. The authority had two major funding powers. First, an annual special excise tax could be levied, not to exceed $1.4 \%$ of the value of every motor vehicle owned by a Seattle resident for the privilege of using a motor vehicle. Second, the authority could issue no more than $\$ 1.5$ billion in bonds for an initial line and planning for a second line.

The monorail authority was structured as a nine-member board, with the Elevated Transportation Company acting as an interim governing body. The interim board and city leaders would appoint some members of the monorail authority's Board, while others would be elected. The eventual goal was for the monorail authority to have most positions be publicly elected (Seattle Monorail Project, 2002).

\section{Planning the Green Line}

In August 2003, the Seattle Monorail Project (SMP) circulated the Seattle Monorail Green Line Draft Environmental Impact Statement (EIS). The EIS studied the environmental impacts of a great number of alternatives for alignment and station locations along the 14-mile Green Line, which would span the Ballard, Interbay, Queen Anne, Seattle Center, Belltown, Downtown, SODO, and West Seattle areas.

The EIS explained how monorail columns could impact marine wildlife in the Ship Canal in Ballard, historical buildings, air and noise pollution. The draft EIS supplied solutions for most of the major environmental impacts; however, there was still room for questions. For example, while the SMP tried to make the monorail as quiet as possible for most areas, there would potentially be a significant amount of unavoidable noise pollution in some neighborhoods. There would be "low to moderate" visual quality impacts in Ballard resulting from stations and guideway structures, and unpleasant visual impact to six historic resources in the Interbay segment.

After the City of Seattle Planning Commission reviewed the draft EIS, it released its comments in October 2003. The Commission suggested that the SMP give more details and information, and said that many aspects needed to be stated in more detail, such as the monorail impact analysis and plans for mitigating possible negative impacts. In December 2003, the Seattle Monorail Project released a preliminary recommendation on the Green Line route and station locations, raising an issue that caused a lot of public argument - the recommendation that the route go through Seattle Center. Here are some of the reactions: 
"Leaders of the Folklife and Bumbershoot festivals are concerned about a compromise that would run the line through, but not down the middle of, the campus,' relates reporter Kery Murakami of the Seattle Post-Intelligencer. 'Perhaps more significantly,' Murakami adds, 'City Council members are voicing worries about slicing through one of the city's icons.' [Seattle Post-Intelligencer 19 March 2003]

"The route dispute has been brewing for months. 'While going around the Center would add time to trips, some balked at the idea of cutting through the middle of the campus, saying it would ruin views and destroy the wide open ambience of the campus,' Murakami reported in an earlier, February, article [Seattle PostIntelligencer, 25 February 2003]

"Nevertheless, the most recent outbreak of the route conflict seemed to catch SPMA planners by surprise. 'Monorail officials had thought they had found a solution to one of the most vexing choices they face: whether to go around or through the Center,' relates Murakami, who explains how the new conflict developed. [Seattle Post-Intelligencer 19 March 2003]” (Light Rail Now, 2003).

\section{Financial Troubles}

According to Barnett (2005) in her article "What Went Wrong," the Seattle monorail financial mistake happened even before the third vote, Seattle Citizen Petition No. 1-Proposed Monorail Authority, which resulted in the creation of the Seattle Popular Monorail Authority (Seattle Monorail Project.) In late summer 2002, Daniel Malarkey, the Seattle Monorail financial consultant, estimated the monorail's tax base by including some areas that are not part of Seattle. This led to an approximately $\$ 1$ billion error in the estimated monorail's tax base. Moreover, in 2003, Malarkey misinterpreted a spreadsheet from the state Department of Licensing by including some cars which were supposed to be exempted from the MVET in the calculation. This resulted in another $\$ 2.3$ billion inflation of the monorail's tax base All these inaccurate estimates of the monorail's tax bases led to around 30\% project revenue shortfall. Malarkey discovered this financial problem in early 2003. The problem was not revealed to the board or public until months later. This induced criticism throughout the city.

\section{Opposition to the New Monorail - Initiative 83}

Monorail antagonists filed Initiative 83, the "Monorail Recall Initiative" in May, 2004. Initiative 83 concerned prohibiting use of City rights-of-way for any new monorail lines: 
"If enacted, the measure would prevent construction of any new monorail lines, such as the Green Line, by prohibiting the City from allowing any new monorail lines to cross or otherwise use City streets or sidewalks. Under this measure, any authorization for use of City rights-of-way for new monorail lines would be revoked." (King County Records, Elections, and Licensing Services Division, 2004).

The Monorail Recall website listed 23 reasons for recalling the monorail (Monorail Recall, 2004) (see Table 2).

Insert Table 2 Here

The Seattle City Clerk forwarded Initiative $83^{2}$ to King County Records and Elections. The proponents needed to collect 17,229 valid signatures by early November 2004 to meet the requirements for placing the initiative on a ballot. The monorail supporters then filed a legal challenge to I-83, arguing that the ballot title was unclear and that the initiative violated both the monorail-specific initiative process in Washington state law and the state's Growth Management Act. Consequently, it was illegal.

In June and July 2004, the track alignment and transit way agreement were approved by the Seattle City Council. Moreover, the SMP Board voted to delay the opening of a short section of line in 2007 and planned to finish the entire 14-mile-long Green Line by June 2009, 6 months ahead of schedule, to save money which would have been lost with the delayed opening of the short section.

King County Superior Court ruled that I-83 was illegal in August, 2004, and ordered King County elections officials not to place it on any ballot at any time. Monorail Recall brought that ruling to the State Court of Appeals and requested that it be determined at the same time if signatures gathered under the vague ballot title should be counted. The State Court of Appeals later issued a decision to dissolve the Superior Court order which stop King County elections from putting I-83 on the ballot. The City Council then placed the I-83 on November 2004 ballot.

According to the Green Line Contract Procurement Process, ${ }^{3}$ the SMP was having confidential negotiations with Cascadia Monorail Company (Cascadia) to create the design,

\footnotetext{
${ }^{2}$ Initiative 83- Monorail Recall: an initiative which would prohibit the Seattle Monorail Authority from building within any City of Seattle right of way.
} 
build, operate and maintain (DBOM) contract, which under Cascadia's proposal would use Hitachi trains (Seattle Monorail Project, 2002b; 2004). Team Monorail, another company, which proposed using Bombardier trains, said that their proposal would be less expensive than Cascadia's and would provide better services. Nevertheless, Team Monorail dropped out of consideration because it was unable to accomplish the monorail agency's liability rules. This made Cascadia Monorail Company the only company to submit a proposal to the City on time. In November 2004, 64\% of the Seattle voters rejected I-83. This allowed the SMP to continue working on the new Seattle monorail.

Cascadia Monorail Company then offered a bounded proposal to the SMP Board. The SMP staff suggested to the SMP Board to approve the Design, Build, Operate, and Maintain (DBOM) contract with the Cascadia Monorail Company. The contract stated that the Cascadia Monorail Company would responsible for design, build, operate, and maintain the monorail for a fixed price ( $\$ 2.1$ billion) and scheduled the monorail to be opened in December 2010. The new contract reduced the number of stations from 19 stations to only 16. Completion deadlines were also set out in the contract, which was finalized on June 17th, 2005.

Afterwards, the SMP finance director misinterpreted the city of Seattle's total tax base, leading to the project's financial disaster. The SMP's Board proposed a new financial plan for the 14-mile Green Line. With the new plan, the $\$ 2$ billion monorail would bear an additional \$9 billion in interest, and taxes would be collected until the year 2050 or longer.

After the declaration and release of the monorail contract, local newspapers exposed that the high interest rate bonds would make the proposed Green Line's cost reaches $\$ 11$ billion instead of $\$ 2$ billion. The extra $\$ 9$ billion was caused by the non-rated bonds issued because the SMP's revenues could not pay off the debt until after the line was built. The agency had to postpone payments until tax revenues from car-tab taxes could cover the cost. One comment from a Seattle Times analysis of the project's finances, "in order to pay off the $\$ 2$ billion monorail within 25 years (closer to the norm of such projects) without using "junk" high interest bounds, we would have to raise the motor-vehicle excise tax (MVET) from $1.4 \%$ to almost 3.9\%" (De Silver, 2005).

Confronting extreme public criticism, the Board abandoned its financial plan. The Board had until mid-December to make a final decision on the separate agreement with Cascadia to 
build the Green Line. The SMP Board held public hearings on the contract during July 5-7, 2005. Then, they decided to adopt a Monorail Action Plan on July 20, 2005. They stated that "the goal of the Monorail Action Plan is to determine the best path for the Seattle Monorail Project through a thoughtful, deliberate and open public process, involving the full Board, with all options on the table and all views considered" (Seattle Monorail Project Board of Directors, 2005). They had to decide whether the SMP would keep the Cascadia contract or re-bid the new contract, and find the ways to create a better financial plan. The action steps from this plan included: cost cutting, independent peer review by outside experts, open brainstorming session with the public, and an executive director search.

In line with those measures, the SMP reduced staff by 30\%. The SMP Board also announced a new independent financial policy analyst, Kevin Phelps.

On August 10, 2005, the independent peer analysis from outside transportation experts reviewed and evaluated the DBOM contract between SMP and the Cascadia Monorail Company. They came up with five different ways to solve the financial problem: vote for more taxes, shorten the line, develop a new financial plan, build the line in phases, or stop the project. An Interim Executive Director was hired to evaluate the steadiness of project and the feasibility of the new financial plan. At the same time, Mayor Nickels also gave the SMP Board the deadline to notify him by September 15 th if they decided to dissolve the agency or to put a measure on the November ballot and let Seattle voters decide whether they want to shorten the Green Line or increase the tax. August 17, 2005, Interim Executive Director was hired to evaluate the steadiness of project and the feasibility of the new financial plan.

\section{The Final Months}

Kevin Phelps, the independent financial policy analyst, submitted a report in late recommending a new financial plan to reduce the monorail's interest from $\$ 11$ billion in 50 years to $\$ 7$ billion in 39 years. He stated that the Design-Build-Operate-Maintain (DBOM) approach was suitable for SMP and also examined possible saving in the DBOM.

Then, on September 14th, the SMP Board followed the recommendation of Interim Executive Director John Haley. By rejecting the other choices such as killing the Project, placing it to a revote, and re-procurement, the SMP decided to continue with the project with one condition that they would hold a special election on February 7, 2006, asking voters' approval for the Green Line Plan changes if they could not progress an appropriate financial plan by 
December 20, 2005. The SMP Board voted to continue its work to improve the new finance plan and not to place a measure on the November 2005 ballot. On the other hand, they would place a measure on the February 2006 ballot if an agreement with the City could not be reached.

The Board's decision not to place a measure on the ballot challenged Mayor Nickels, who had set the deadline for the board to choose whether to dissolve the agency or place a measure on the November ballot. Mayer Nickels withdrew his support for the project on September 16, 2005, with the reason that the project's financial plan "did not protect taxpayers or the city."

Seattle City Council unanimously voted to endorse the Mayor's cancellation of the transit way agreement the day after the SMP Board's decision. The SMP Board then capitulated to placing a measure on the November 2005 ballot (Proposition No. 1 - Construction of Monorail by Modifying Plan, the ballot measure which would authorize the building of a 10-mile line between West Seattle and Interbay.) If the Proposition were rejected, the monorail project would be killed.

The Official Text of Proposition No.1 highlighted the crucial nature of the ballot:

"The Board of Directors of the Seattle Monorail Project adopted Resolution No. 05-36-A which concerns constructing a monorail by modifying the Seattle Popular Monorail Plan. This measure would modify the Plan to allow SMP to: initially build a monorail from Dravus (Interbay) to Alaska Junction (West Seattle); further modify the Plan's route if necessary to obtain City consent for construction permits following City review of SMP's finance plan; and, if possible, build the remainder of the 14-mile Green Line. If this proposition is enacted, SMP would be directed to build a monorail. If it is rejected, no new monorail would be built. Should this proposition be enacted in law?" (Municipal League of King County Ballot Issues Committee, 2005).

November 8, 2005, 64.51\% of Seattle voters voted against Seattle Popular Monorail Authority Proposition No. 1. The SMP reached the end of the line. The MVET tax would continue until the SNB agency's debt was paid off. November 9, 2005, the SMP Board took essential steps to terminate the SMP.

\section{Using Stakeholder Theory to Analyze the Seattle Monorail Project}

Seattle is one of the worst cities for traffic in the US. According to the website infoplease.com (Infoplease, 2006), in 2002, Seattle was ranked as the fourth worst congested city in the US. To 
alleviate traffic congestion in Seattle, the City of Seattle aimed to develop an integrated transportation system. A key part of the proposed system was a monorail. While the City's overall strategic intention of developing a monorail is innovative, it is clear from events that the strategy failed to be implemented. Many public organizations face similar situations: a creditable strategy that fails to reach fruition. We argue that the implementation of innovative strategies requires a stronger emphasis on stakeholders than has been evident in previous literature. In this section, we use stakeholder theory as a lens through which to penetrate the morass of the SMP.

Broadly speaking, we can identify nine critical stakeholder categories. Each category can be subdivided into several separate stakeholders as exemplified by the category Seattle citizens which numbers many millions of individuals. Stakeholder categories are porous as specific stakeholders can fit into more than one category. For example, a group might be part of the Anti Monorail pressure group as well as potential passengers. Each stakeholder has its own interests and expectations of the Seattle Monorail Project. We examine each in more detail.

\section{Politicians}

This category of stakeholder includes Seattle's Mayor, the City Council and Council members. Mayor Nickels initially supported the Seattle Monorail Project and cited it as one of his outstanding works. We can see this from the Seattle Weekly (Bush, 2001), in which the mayor said that Seattle had to build the monorail: "Voters have already told us twice they want us to build the monorail." However, this support waned after the collapse of the SMP financial plan, and the resignation of SMP executives-Board Chairman Tom Weeks and Executive Director Joel Horn resigned from their positions on July 4, 2005, due to their failure to recognize financial problems facing the SMP. By August 2005, the Mayor's used his power to influence the direction of the SMP. He gave the SMP Board the deadline of September 15 to notify him if they decided to dissolve the agency or to put a measure on the November ballot that would let Seattle voters decide whether they wanted to shorten the Green Line or increase the tax. The Mayor's position changed radically from the start of the project by September $16^{\text {th }} 2005$. He withdrew his support of the SMP because, in his view, the project had a "risky financial plan that did not protect taxpayers or the city" Mayor Nickels then acted by blocking permits to build the line. 
In terms of the City Council, some members were for and others against the SMP proposal. When it came time to assign the proposal to a committee for discussion, City Council members Richard McIver, Heidi Wills, Jan Drago, and Jim Compton voted against discussing the initiative further. According to M. Tomchick in the article "Gridlock Forever," Richard Mclver, the Chair of the Council's transportation committee, had been involved in planning the light rail - Sound Transit (Tomchick, 2000). Since the Sound Transit is one of the projects that the City of Seattle developed to help reducing traffic problem, the monorail project became a big competitor that could pull financial support from the Sound Transit. According to this article, "McIver has never let an opportunity to slam the monorail pass him by" (Tomchick, 2000).

The City Council influenced the development plans of the monorail. They made a request that the SMP "postpone the execution of the DBEC, OMC (Elevated Transportation Company, 2006a) and other agreements until after the City Council determines that the Seattle Monorail System is (or is not) financially viable and allows (or disallows) the City's rights-ofway to be used, pursuant to the Transit Way Agreement" (Municipal League of King County, 2005). This had two key consequences. One, the scheduled opening date of the monorail was put back from 2009 to 2010. Two, costs escalated - for example, the project faced an increase in debt interest of $\$ 9$ billion.

\section{Seattle Citizens}

This stakeholder is interesting for a number of reasons. One, there are a myriad of individual stakeholders that make up this category. Each of these has their own set of interests and expectations and it is highly unlikely that an organization can meet all these equally. Two, an individual in this category can occupy several different roles - a Seattle citizen can be a taxpayer, a commuter and / or a voter. As a taxpayer, citizens want to maximize the use to which their tax dollars is being put and they want to minimize the amount of tax they pay. As a commuter, they want to avoid being stuck long traffic jams and want to get from one point of the city to another in the shortest time possible. As a voter, they want to make choices over transportation options. Three, there are obvious trade-offs between the expectations of citizens depending on the guise in which they appear. For instance, commuters get a quicker traveling time but might have to pay more tax.

In terms of the MSP, Seattle citizens (as commuters) supported the development of the monorail. In November 2004, 64\% rejected I-83, which allowed the Seattle Monorail Project to 
continue to be developed. The majority of Seattle citizens (as voters) didn't mind paying the higher motor vehicle excise tax. We know that because the Seattle voters had already known about the $1.4 \%$ motor vehicle excise tax, and the majority of the Seattle voted for the tax proposal. To this extent Seattle citizens (as voters) supported the development of the monorail. However, as the project developed delays and cost overruns became apparent, Seattle citizens (as taxpayers) withdrew their support because they didn't agree to pay excise taxes for nearly 50 years in the future to fund the monorail.

\section{SMP Board}

The SMP Board is made up of several critical roles including the Board Chairman and Executive Directors. This group took all key decisions. The SMP board held public hearings and decided to adopt a Monorail Action Plan. "The goal of the Monorail Action Plan is to determine the best path for the Seattle Monorail Project through a thoughtful, deliberate and open public process, involving the full Board, with all options on the table and all views considered" (Seattle Monorail Project Board of Directors, 2005). The Board also voted to delay the opening of a short section of line in 2007 and planned to finish the entire 14-mile-long Green Line by June 2009, 6 months ahead of schedule, to save money which would have been lost with the delayed opening of the short section.

Many of the Board members had little or no mass transit experience. The Board was unaware about what was going on below management. The SMP finance director misinterpreted the city of Seattle's total tax base which led to a gross financial miscalculation. This information was kept from the public. According to the Seattle Post-Intelligencer, the monorail expected to get \$4.2 million a month for revenue in April, but they only received around \$2.2 million in June and \$2.24 million in July. It was about 48\% below projections (Hadley, 2003). Then, the SMP Board came up with a new financial plan that would require the tax payers more than 50 years to pay off for the monorail. This drew serious criticism in the city. The SMP Board then abandoned its finance plan, and the agency's top two executives, Board Chairman Tom Weeks and Executive Director Joel Horn, resigned from their positions on July 4, 2005. According to the Puget Sound Business Journal, they said in their resignation letter, "The board and the people of Seattle have made it clear that the proposed financing plan will not work and that a better plan must be developed....We take full responsibility for the current situation and feel that it is in the best interest of the project to step down" (Puget Sound Business Journal, 2005). 
Following these resignations, Interim SMP leaders then assumed responsibilities. The Board had until mid-December to make a final decision on the separate agreement with Cascadia to build the Green Line. The new Board then evaluated the project and feasibility of the new financial plans. The SMP board chose to follow the recommendations of Interim Executive Director John Haley to continue looking for a way to build a new financial plan and refused to place a measure on the November ballot. Mayor Nickels then withdrew his support for the project, with the reason that the "risky financial plan that did not protect taxpayers or the city," and blocked permits to build the line. The SMP Board members voted again one day later and put the Seattle Monorail project on the November ballot, letting Seattle voters decide between approving a shorter 10.6-mile monorail system from West Seattle to Interbay and shutting down the project. The Seattle Monorail Project reached the end of the line after $64.51 \%$ of the Seattle voters voted against the Seattle Popular Monorail Authority Proposition No. 1, Construction of Monorail by Modifying Plan.

\section{Anti Monorail Pressure Groups}

This stakeholder category ranged from organized groups to anonymous individuals such as bloggers. An organization Monorail Recall was created to stop the Seattle Monorail Project. This group did not believe that they Seattle Monorail would be financially self-sustaining. They suspected that the SMP would require higher taxes for Seattle taxpayers. Monorail recall were unconvinced about how the Motor Vehicle Excise Tax (MVET) calculated. The taxable value of the vehicle was not based on market value price. The tax was based on $95 \%$ of the manufacturer's suggested retail price less options for the first year and $89 \%$ for the second year. This would make the tax higher than it should be. Monorail Recall took decisive action to stop the SMP. They launched the "Monorail Recall" Initiative (Initiative 83) in 2004. This required Seattle voters to vote on a ballot to stop the development of a monorail system. The Seattle Monorail Project mounted a legal challenge to this action on the basis that the ballot title was unclear and that the initiative violated both the monorail-specific initiative process in Washington state law and the state's Growth Management Act, and consequently was illegal. Nonetheless, Seattle voters had to vote to save the project, which they did. There are two critical consequences of Monorail Recall's actions. The first is that they caused uncertainty about the monorail project - plans couldn't progress smoothly because the entire project might stop. The 
second is that the overall costs of the project increased. Both these consequences made the development of the monorail that much more difficult.

At the other end of the spectrum of stakeholders in this category, the Seattle Monorail Project faced resistance from anonymous sources. One, for example, is the blogger "Kermit" who commented extensively on the Seattle Monorail technology:

"The monorail proposal calls for platforms measuring roughly 140 - 160 feet in length and between 22 and 27 feet in width. Based on the I-83 site, the size of the platforms has been reduced to around 90 feet in length. The straight dope here is that this is a serious limitation. Stations built to this standard will likely be difficult to upgrade to a 'full length' platform and the right of way costs could be exorbitant" (Kermit, 2004)

With regard to single-beam construction, Kermit said:

"Like the platform lengths, this issue is again attributed to budgetary measures. There are five sections, depending on how you want to count it, of single beam section. The entirety of the single section track exists near the terminus at each end. All of the downtown area of the monorail is double track sections. Notable is that the single section track exists in areas where there are few stations which should speed transit and reduce possible delays."

Kermit noted an important point about the single beam issue:

"Any time a single point of failure is introduced into a system, you should be wary. And this will be an Achilles' heel for the system until such time that the track can be expanded to two lines. Which raises an interesting point; for light rail, addition of lines requires additional right of way costs. For the monorail, the right of way already exists and a second line can be quickly added to existing support structures."

Stakeholders who make themselves powerful, such as Kermit, are highly difficult to manage because they speak knowledgeably about the subject, they raise issues and concerns that fuel doubt and uncertainty, and most critically they are invisible to SMP.

Falling somewhere in-between organized groups such as Monorail Recall and individuals such as Kermit are other stakeholders. For example, recognized experts in the field. The Seattle Monorail Project faced one such stakeholder. Jon Magnusson, a respected member of the engineering community, called a press briefing in his office in May 2004. He used a train set to model aspects of the proposed monorail such as the switch from two beams to one. During the briefing he raised the following questions: "Is the monorail being laid out properly in 
anticipation of expanding it citywide? Will the single-track design of portions of the route serve future ridership growth? And is there a possibility the West Seattle Bridge might cave under the added weight of a monorail track if struck by an earthquake?"(Anderson, 2004).

His criticisms forced SMP to react. The monorail construction team said that Magnusson's questions were neither new nor unanswered, and nothing that they "haven't discussed and gone over with the public at community meetings" (Anderson, 2004). An SMP spokesperson had to remind the public that the monorail project had some of the best people with significant transit systems development capabilities and experience. The spokesperson defended the monorail plans: The expansion planning, single-track sections, and bridge load are issues all resolved in environmental impact statements and other planning documents, he said" (Anderson, 2004).

However, as indicated by the Seattle Monorail documents, there were a lot of "unclear" answers for these questions. For example, there were issues about the single track sections, and in relation to the bridge load issue, the SMP gave this answer:

"To cross the Duwamish, engineers have confirmed that the best way would be to build the monorail guideway on top of the existing West Seattle Bridge, running along the center without taking away any traffic lanes. Their studies indicate the West Seattle Bridge can be strengthened to hold the monorail, and a recent City of Seattle review agrees" (Elevated Transportation Company, 2002a).

However, there was no explanation about what the studies were about, which "indication" had shown that the West Seattle Bridge could be strengthened to hold the monorail, or what the current earthquake-resistant construction requirements were. Magnusson tapped into concerns of Seattle voters which made them feel less comfortable with supporting the project. SMP should have given more explanations and provided more evidence to support the engineering concerns.

\section{Monorail Supporters / Activists}

In contra-position to the Anti Monorail pressure groups, there is another category of stakeholders, namely Monorail supporters. Again these can be organized groups or individuals. According to the Seattle Monorail Project website (Elevated Transportation Company, 2006b), "the pro-monorail coalition included individual taxpayers; small businesses; the Seattle Mariners Baseball Club; the Space Needle; the Seattle/King County Building and Construction Trades Council; the AFL-CIO, an organization representing 27 local union affiliates and 20,000 trades people in King County; former U.S. Senator and Washington State Governor Dan Evans; 
environmental leader and coordinator of Earth Day, Denis Hayes; civic leader and businessman Tomio Moriguchi, Chairman \& CEO of Uwajimaya, Inc.; Nitze-Stagen, a commercial office, industrial and retail developer and owner of the Starbucks headquarters building in the old Sears Tower; the Transportation Choices Coalition, comprising 700 members and 53 organizational partners dedicated to finding alternatives to dependence on single occupancy vehicles; and the Seattle Monorail Project."

This list reflects the diverse nature of the monorail supporters. These supporters had to fight repeatedly with opponents. For example, they filed a lawsuit against the city in King County Superior Court to implement Initiative 41, which established the Elevated Transportation Company, to seek private capital and management. The supporters argued that that the city had to give financial support for the monorail project in the event of no other investors getting involved. In another example, supporters gathered more than 20,000 signatures to start Initiative 53, which authorized \$6 million for a new monorail plan and reserved \$200 million in municipal borrowing capacity for its possible implementation. In November 7, 2000, Initiative 53 was approved by a $56 \%$ of the Seattle voters.

\section{Contractors}

These are organizations that would build the monorail such as Team Monorail and Cascadia Monorail Company (Cascadia) in the form of physical assets. This category also includes the Elevated Transportation Company (ETC) which manages intangible assets such as capital and management.

Contractors of physical assets had to follow the Green Line Contract Procurement Process (Seattle Monorail Project, 2002b; 2004). Initially there were two organizations vying for the contract to build the monorail. The Seattle Monorail Project started confidential negotiations with Cascadia to create the design, build, operate and maintain (DBOM) contract, which under Cascadia's proposal would use Hitachi trains.

Cascadia offered a bounded proposal to the SMP board in April 2005. Then in June 2005, the SMP staff suggested to the SMP board to approve the Design, Build, Operate, and Maintain contact with the Cascadia. The contact stated that the Cascadia would design, build, operate, and maintain the monorail for a fixed price ( $\$ 2.1$ billion) and scheduled the monorail to be opened in December 2010. The differences between the original proposal and this DBOM contact was the 
stations were reduced from 19 stations to only 16 stations. Completion deadlines were also set out in the contract, which was finalized on June 17th.

The other contractor, Team Monorail, proposed using Bombardier trains because this would reduce costs, would be less expensive than Cascadia's and would provide better services. Nevertheless, Team Monorail dropped out of consideration because it was unable to accomplish the monorail agency's liability rules. This made Cascadia Monorail Company the only company to submit a proposal to the City on time.

The ETC was influential in the choice of the technology for the Seattle Monorail Project. It opted for traditional monorail technology over other technologies was because traditional technology had a proven track record, could travel at speeds over 50 miles per hour, and could be configured to easily accommodate 3,000 plus passengers per hour per direction when trains were operating every four minutes. The ETC also played a part in the design of the monorail. For example, on the elevated.org website (Elevated Transportation Company, 2003), ETC explained suggested a single beam in some areas of the project in order to improve the urban environment and to reduce building costs.

\section{SMP Staff}

These were the people working on the monorail project. SMP staff were crucial to the development of proposals and options for senior managers to take decisions. They were also at the heart of assessing contractors and making recommendations about the actual choice of contractor. As the project approached termination SMP staff felt the impact directly. In July 2005, the SMP reduced staff by 30 percent. Later that year, staff levels were reduced to only those levels needed to terminate the Seattle Monorail Project.

\section{Potential Passengers}

This stakeholder was barely considered by the SMP. They were unclear as to who the passengers on the monorail would be. They were unsure if potential customers would come from the people who normally drove to work, or from customers who normally took a bus. While predictions of the numbers of passengers were made, these were not really tested to check if the projections were accurate. 


\section{Media}

This stakeholder also appears to have been poorly managed. Yet they are very powerful stakeholder. After the declaration and release of the monorail contract, local newspapers exposed that the high interest rate bonds would make the proposed Green Line's cost reach $\$ 11$ billion instead of $\$ 2$ billion. The extra $\$ 9$ billion caused by the non-rated bonds which needed to be issued because the SMP's revenues would not have been adequate to pay off debt until after the line was built. One comment from a Seattle Times analysis of the project's finances (De Silver, 2005), in order to pay off the $\$ 2$ billion monorail within 25 years (closer to the norm of such projects) without using "junk" high interest bounds, we would have to raise the motorvehicle excise tax (MVET) from 1.4\% to almost 3.9\%. This had the potential of causing greater uncertainty over the project's viability.

\section{Other Seattle Residents}

The Seattle Monorail Project touched virtually every aspect of the City of Seattle. Other residents had concerns about the effects on the monorail on historical buildings. Others were concerned about issues such as parking, noise pollution, and the environment. The concerns of local businesses and neighborhoods were again barely considered during the project. People were worried that the higher taxes brought about by the monorail might drive businesses out of the Seattle area which would adversely affect employment.

\section{Independent Analysts}

This stakeholder category includes organizations and individuals who are expected to take a nonpartisan stand in relation to the SMP. This stakeholder category is exemplified by the Board appointment of an independent financial policy analyst, Kevin Phelps in July 2005. Independent

analysts also included external transportation experts who carried out an independent peer review of the SMP / Cascadia contract. They evaluated the DBOM contract and came up with five different ways to solve the financial problem: vote for more taxes, shorten the line, develop a new financial plan, build the line in phases, or stop the project.

\section{Strategic Interactions between Stakeholders}

The stakeholder groups identified above did not operate in a vacuum. They interacted not only with SMP but also with each other. We concentrate our discussion here on the some of the key interactions that led to the demise of SMP. Politicians were keen to address the traffic problems 
facing their constituents in Seattle. They supported the idea of introducing a new monorail system across the City. They wanted to ensure they had public backing and asked Seattle's citizens to vote for it. The voters backed the plan for a monorail, which in effect was the mandate to proceed. Instead, this lead to creation of Monorail Recall - the anti-monorail pressure group. They led the attack by challenging the development of the monorail in Court. The SMP Board reacted by defending their plans. Meanwhile, pro-monorail supporters formed another pressure group to try to get the monorail approved. The media reported on the developments which, over time, created some amount of doubt in the minds of the voters. Politician that were at one time for the monorail scheme turned against it. Those politicians that were against the monorail had their views expressed by the media and through the anti-monorail lobby.

These interactions support Rowley and Moldoveanu's (2003) argument that stakeholder groups form not only because they have common interests but also because the members of the group share some common identity. The pro-monorail activists that supported the project ranged from individuals and local businesses to Trades Councils and Seattle Mariners Baseball Club. This diverse group formed because they had something in common, namely getting the monorail agreed. Where our work goes beyond Rowley and Moldoveanu's (2003) is in highlighting that in addition to having to deal with hostile stakeholders organizations also have to manage friendly stakeholders. The public battles being fought in the Courts and through the media between the anti-monorail contingent and the pro-monorail supporters took its toll on the support the Project got from politicians and voters. The extent to which SMP's board managed the range of stakeholders' interactions is at not evident in the data.

\section{Discussion}

According to the Seattle Transit Study for Intermediate Capacity Transit, the key to Seattle's transportation success would be "an integrated transportation network" (City of Seattle Strategic Planning Office, 2001). Many options were considered including a Bus Rapid Transfer, Street Cars and Trams and Elevated Monorail. After much analysis, a monorail seemed to be the best and most innovative idea for a traffic solution at that time. This led to the creation of the Seattle Monorail Project. However, in spite of Seattle citizens voting in favor of the monorail on four separate occasions - the monorail project still failed. 
There are many conventional strategic analysis frameworks such as a Strengths, Weaknesses, Opportunities and Threats that could be used to analyze the case of the SMP. While these are useful, they provide a weak basis for generalizing the findings more widely. Therefore, we have used stakeholder theory as a framework to analyze the case, in order to draw out propositions that can be generalized theoretically. From a strategic perspective, it is essential that organizations consider stakeholders because stakeholder theory argues that choices made and decisions taken by management should be a function of the organization's choice to satisfy its stakeholders' expectations (Brenner \& Cochran 1991; Carroll 1993; Rowley 2004). Consequently, the selection and importance ascribed to stakeholders can affect its longer-term survival. Organizations that fail to recognize or acknowledge stakeholders that can exert power and influence over their strategy are unlikely to implement the strategy (Byrne \& Polonsky 2001).

The Seattle Monorail Project had a large number of stakeholders. These stakeholders adopted a position in relation to the SMP. Most were positive while others, such as Monorail Recall, were clearly negative. These positions are not fixed either in relation to SMP nor in relation to one another. For example, Seattle's mayor was at first very supportive of the monorail project. However, as it became evident that the project was not going to be implemented his position changed to one that was less supportive. At a simplistic level, this could be explained by the fact that he is a politician and politicians regularly change their position to be seen a favorable light. This is superficial because stakeholder theory suggests that organizations should expect stakeholders to change their positions. The extent to which organizations monitor and manage the change in position is therefore critical. There is no evidence that the SMP had in place any mechanisms for evaluating stakeholders and their relative positions over time. Thus, we suggest that:

\section{Proposition \#1:}

Organizations are more likely to succeed when have effective mechanisms for monitoring and evaluating interactions between stakeholders and changes in their positions in relation to their strategic innovation projects.

In an ideal world all stakeholders will have the same expectations and interests. However, as the Seattle Monorail Project discovered there are deep divisions and conflicts in the expectations. These can be within a stakeholder category or between stakeholders. For example, 
a Seattle citizen might expect to make shorter journey times by using the monorail but the same citizen expects not to pay taxes that are too high. There are also conflicts between stakeholder categories: Supporters of the monorail project expect it to proceed smoothly whereas those stakeholders against the project will take actions to disrupt the project. In effect, organizations face a tradeoff between stakeholders expectations because there in usually insufficient resources to satisfy all stakeholders and meet every interest. In pleasing one group, organizations often had to displease another. Using stakeholder theory we suggest that such tradeoffs need to be managed. Instead, we see that the SMP had no methods by which to deal with conflicts in expectations and interests. The SMP put forward weak counter-arguments in response to experts that made adverse comments about the monorail project or raised questions about its viability these were.

Proposition \#2:

Organizations are more likely to succeed when they tradeoff the conflicts in expectations and interests that stakeholders hold.

It is not uncommon to find organizations in one of three categories in relation to stakeholders' expectations or interests. One category is made up of organizations that don't have a clearly defined view of what their stakeholders expect of them. A second category has organizations that have an excellent understanding of what one or two stakeholders expect but are oblivious to other stakeholders. The most studied stakeholders are usually customers, shareholders and employees. Often one stakeholder is privileged over and above all other stakeholders. The third category contains the very small number of organizations have a good understanding of all its stakeholders' expectations. Moreover, once organizations have an understanding of the expectations it is essential they understand the interactions between stakeholders and their expectations.

The problem organizations in the first two categories face is that their actions can have unintended consequences in relation to the expectations. In the SMP case, the development of a monorail across the City of Seattle could adversely affect other forms of transportation such as buses and the Sound Transit system. While the SMP pursued meeting the expectations of Seattle citizens by promoting the monorail, it was also disengaging the head of the Transportation Committee who criticized the monorail at every opportunity. Comments in the press and from anti monorail groups led to Seattle's citizens losing confidence in the monorail project. 
Proposition \#3:

Organizations are more likely to implement complex technology projects by understanding stakeholders' expectations and the interplay between stakeholders.

Stakeholder theory suggests that all organizations have stakeholders whether or not they are recognized as such. The theory also suggests that these stakeholders have or able to exert some power of the organization. What is lacking from the current theoretical discourse is the source of any stakeholders' power. This apparent gap in the literature leads to all stakeholders being treated as equal - although in practice it is clear that they are not all equal. We posit that stakeholders' power is embedded in the strategic objectives of an organization. To be clear, we argue that every strategic objective has implied within it a set of stakeholders. Thus, in the case of SMP the strategic objectives were to reduce traffic congestion levels, enable faster travel across Seattle, to develop and build a monorail transit system and to meet budges and timescales. Stakeholder categories become clearer in the light of these objectives: Seattle's citizens, politicians, other Seattle residents and contractors. Moreover, the objectives enable organizations to identify those stakeholders that have indirect power over the objectives, specifically those that object to the objective in the first place. In SMP's case these would include the Anti Monorail pressure groups, politicians and, potentially, certain sections of the media.

\section{Proposition \#4:}

Organizations are more likely to achieve their innovative projects when they define stakeholders in terms of their power over their strategic objectives

\section{Conclusions}

Our intention in this paper is to shed light on why large scale innovative technology projects fail. To do so we used stakeholder theory as the lens through which to examine the case of the Seattle Monorail Project. We found that as a result of our work we could make a contribution to the development of stakeholder theory from empirical data. Whereas much of the literature focuses on specific types of organizations or categories of stakeholders, we looked at the range of stakeholders: those for, against and indifferent to the focal organization. Our research supports what is in the current literature, namely that relationships between the focal organization and the stakeholders and their interests are important. Our research when beyond this by also finding 
that interaction between stakeholders is also vitally important to the focal organizations success. An inability or failure to manage these can lead to disastrous outcomes, as SMP discovered. Much of the current literature focuses on identifying stakeholders on the basis of vague terms such as 'interests', 'outcomes' and 'stake' in relation to an organization. Instead, we add to the body of stakeholder theory by suggesting that stakeholders' ought to be with reference to the strategic objectives the organization is aiming to achieve. This can remove blind spots: not seeing individuals or groups as stakeholders simply because the organization does not deal with them currently. Stakeholders have conflicting interests and expectations of the organization. These conflicts, unless managed and resolved, can lead to adverse outcomes for the organization. When viewed from the perspective of stakeholder theory, even those groups and individuals that are deeply entrenched against the organization need to be listened to in the first instance. Their concerns and anxieties cannot be ignored. The SMP board appears to have been unprepared for such a strong anti-monorail pressure group to build up. The board seems to have been on the back foot; reacting to events brought about by contractors, the anti-monorail group, the media and politicians. This suggests that managing interactions between stakeholder groups and between the stakeholders and the organization might well be more important than the work being done to develop the innovation. We argue that SMP's failure to manage its stakeholders effectively has meant that Seattleites continue to face significant traffic problems. The failure of the SMP teaches a good lesson not only to the City of Seattle but also to other cities that may consider starting similar projects.

\section{References}

Anderson, R. (2004) Credible critic. Seattle Weekly, May 26, 2004. Retrieved November 27, 2006, from http://www.seattleweekly.com/news/0421/040526_news_monorail.php

Anonymous. (2006) Groups quick to criticize monorail support plans. The Jakarta Post, August 29, 2006, 1.

Atkinson, A. A., Waterhouse, J. H. \& Wells, R. B. (1997). A stakeholder approach to strategic performance measurement, Sloan Management Review, 38, 3, 25-37.

Barnett, E.C. (2005) What went wrong? The stranger from November 17-November 24, 2005. Retrieved February 3, 2007, from http://www.thestranger.com/seattle/Content?oid=25271

Brooks, F. (1987) No silver bullet: essence and accidents of software engineering. Computer, 20, 10-19. 
Bush, J. (2001) Do nice guys finish first? Seattle Weekly, July 4, 2001. Retrieved November 17, 2006, from http://www.seattleweekly.com/news/0127/news-bush.php

City of Seattle. (2004) Seattle city council 2004 significant vote log. Retrieved December 25, 2006, from http://www.seattle.gov/leg/clerk/sv2004.htm

City of Seattle. (2006) Monorail milestones. Seattle Channel: In Depth: Monorail. Retrieved October 26, 2006, from http://www.seattlechannel.org/issues/monorail.asp

City of Seattle Strategic Planning Office. (2001). Seattle transit study for intermediate capacity transit. Retrieved December 30, 2006, from http://www.seattle.gov/transportation/Stage2Documents/ICTsummary.pdf

Collingridge D \& Margetts H (1994) Can government information-systems be inflexible technology - the operational strategy revisited, Public Adminsitration,72 (1): 55-72

De Silver, D. (2005) No painless solution to monorail crisis. Seattle Times, July 5, 2005.

Retrieved December 28, 2006, from http://seattletimes.nwsource.com/html/localnews/2002357623_monofinance05m.html

Donaldson, T. \& Preston, L. E. (1995) The stakeholder theory of the corporation: Concepts, evidence, and implications. Academy of Management Review, 10, 65-91.

Elevated Transportation Company. (2002a) Seattle Monorail Project- Frequently Asked Questions "How will the Green Line cross the Ship Canal to Ballard and the Duwamish to West Seattle?" The Seattle Monorail Project. Retrieved on November 27, 2006, from http://archives.elevated.org/project/faq.shtm

Elevated Transportation Company. (2002b) Building the Monorail: Seattle popular transit plan Draft 2. Retrieved January 30, 2007 from http://archives.elevated.org/draft_sptp/Draft_SPTP.pdf

Elevated Transportation Company (2002c) ETC Seattle popular monorail plan. Building the Monorail. Retrieved October 26, 2006, from

http://archives.elevated.org/final_spmp/final_spmp.pdf

Elevated Transportation Company (2006a) Project description. Board of Directors. Retrieved February 5, 2007, from http://www.elevated.org/project/board/newplan/

Elevated Transportation Company (2006b) Initiative 83, Monorail recall rejected by voters. Retrieved December 31, 2006 , from www.elevated.org/project/faq/faq.asp?faqid=52

Elevated Transportation Company. (2003) Single beam guideway. Retrieved November 19, 2006 from http://www.elevated.org/_downloads/project/updates/singleBeamSummary.pdf

Federal Highway Administration Office of Operations (2005) Traffic congestion and reliability: Trends and advanced strategies for congestion mitigation. November 10, 2005. Retrieved December 19, 2006, from http://ops.fhwa.dot.gov/congestion_report/executive_summary.htm\#trends

Foster, G. (2001) New report: Seattle's traffic second worst in nation. Seattle Post-Intelligencer, May 7, 2001. Retrieved December 20, 2006, from

http://seattlepi.nwsource.com/transportation/21902_congestweb.shtml

Freeman, R. E. (1984) Strategic management: A stakeholder approach. Pitman, Boston. 
Freeman RE \& Reed DL (1983) Stockholders and stakeholders - a new perspective on corporate governance, California Management Review 25 (3): 88-106

Friedman, A.L. \& Miles, S. (2002) Developing Stakeholder Theory. Journal of Management Studies, 39 (1), 1-21.

Frooman, J. (1999) Stakeholder influence strategies. Academy of Management Review, 24, 191205.

Greasley, A. (2004) Process improvement within a HR division at a UK police force. International Journal of Operations \& Production Management, 24, 3, 230-240.

Hadley, J. (2003) Monorail revenue remains far short. Seattle Post-Intelligencer, August 21, 2003. Retrieved January 9, 2007, from

http://seattlepi.nwsource.com/transportation/136023_monorail21.html

Iacovou C.L. \& Dexter, A.S. (2004) Turning around runaway information technology projects California Management Review 46 (4): 68-75.

Kermit (2004) Seattle monorail: Lunacy or legitimate? Message posted on November 8, 2004 to http://www.reload.ws/blog/2004/11/seattle-monorail-lunacy-or-legitimate.html

King County Records, Elections, and Licensing Services Division. (2004) City of Seattle Initiative No. 83. Ballot Measures, Nov. 2, 2004 General and Special Elections. Retrieved December 26, 2006, from http://www.metrokc.gov/elections/2004nov/measures.htm\#sea83

Johnson, K. (2005) Denver airport to mangle last bag. The New York Times, August, 27, 2005. Retrieved May 5, 2007, from http://www.iht.com/articles/2005/08/26/news/denver.php

Infoplease. (2006). Traffic congestion in U.S. cities, 2002. Infoplease-All the knowledge you need. Retrieved November 18, 2006, from http://www.infoplease.com/ipa/A0855647.html

Light Rail Now. (2003) Seattle: Huge monorail project faces growing community squabbles. Retrieved December 25, 2006, from http://www.lightrailnow.org/news/n_monorail001.htm

McAfee, A. (2003) When too much IT knowledge is a dangerous thing. Sloan Management Review, 44, 83.

Mitchell, R.K., Agle, B.R. \& Wood, D.J. (1997) Toward a theory of stakeholder identification and salience: Defining the principle of who and what really counts. Academy of Management Review, 22, 853-886.

Montealegre R \& Keil M (2000) De-escalating information technology projects: Lessons from the Denver international airport MIS Quarterly 24 (3): 417-447.

Monorail Recall. (2004) 23 reasons for recall. Monorail recall. Retrieved January 1, 2007, from http://web.archive.org/web/20040803130712/http://exordia.net/monorailrecall/23reasons.htm

Municipal League of King County Ballot Issues Committee. (2005) Report on Seattle Proposition 1 Seattle Popular Monorail Authority (Seattle Monorail Project) Construction of Monorail by Modifying Plan. Retrieved December 28, 2006, from http://www.munileague.org/ballotissues/2005/Monorail\%20_BIC\%20 
Municipal League of King County. (2005) Resolution relating to the Seattle Monorail Project. June 20, 2005. Retrieved January 1, 2007, from

http://www.munileague.org/issues/2005/monorail/Monorail-Council\%20Resolution-FNL.htm

Post, J. E., Preston, L. E. \& Sachs, S. (2002) Managing the extended enterprise: The new stakeholder view. California Management Review, 45, 1, 6-28.

Powell, M. (2004) Boston's big dig awash in troubles: Leaks, cost overruns plague project. The Washington Post, November 19, 2004. Retrieved on May 5, 2007 from

http://www.washingtonpost.com/wp-dyn/articles/A61112-2004Nov18.html

Puget Sound Business Journal. (2005) Leaders quit the Seattle Monorail Project. Puget Sound Business Journal, July 4, 2005. Retrieved January 7, 2007, from http://www.bizjournals.com/seattle/stories/2005/07/04/daily1.html

Roepke, R., Agarwal, R. \& Ferratt, T. W. (2000) Aligning the IT human resource with business vision: The leadership initiative at 3M. MIS Quarterly, 24, 2, 327-353.

Rowley, T. J. \& Moldoveanu, M. (2003) When will stakeholder groups act? An interest-and identity-based model of stakeholder group mobilization. Academy of Management Review, 28, 2, 204-219.

Schumaker, G. (2006) Former champion disheartened by monorail miscues. Las Vegas Review, July 20, 2006, 3D.

Scigliano, E. (1998) Monorail: Back to the future. MIT Technology Review, 101 (2), 19-21.

Seattle Monorail Project. (2002a) Seattle Monorail Authority Seattle Citizen Petition No. 1. Retrieved December 25, 2006, from http://www.elevated.org/_downloads/board/petition1.pdf

Seattle Monorail Project. (2002b) Seattle Monorail Project Resolution 02-10 Exhibit A:

Procurement Options for the Seattle Monorail. Retrieved January 7, 2007, from

http://elevated.org/_downloads/meetings/02-10_Procurement_ExhibitA.pdf

Seattle Monorail Project. (2004) Green Line Contract Procurement Process. Fact Sheets and FAQs. Retrieved December 26, 2006, from http://www.elevated.org/project/faq/faq.asp?faqid=53;

Seattle Monorail Project. (2005) Design-build-equip contract-Seattle monorail green line. June 17, 2005. Retrieved December 27, 2006, from $\mathrm{ftp} / / / \mathrm{www} . e l e v a t e d . o r g /$ contract/dbec/DBEC_Final.pdf

Seattle Monorail Project Board of Directors. (2005) Monorail Action Plan. July 19, 2005. Retrieved December 29, 2006, from http://www.elevated.org/project/board/actionplan/

Seattle Popular Monorail Authority Board of Directors. (2005) Resolution No. 05-39 authorizing staff to take steps necessary to terminate the Seattle monorail project. November 9, 2005.

Retrieved December 20, 2006, from http://seattlemonorail.org/_downloads/project/board/actionplan/Res_05-

39_Authorizing_Staff_to_Take_Steps.pdf 
Washington State Legislature's website (2003) RCW 35.95A.120, Dissolution of authority. Retrieved February 3, 2007, from http://apps.leg.wa.gov/RCW/default.aspx?cite=35.95A.120 2045 Seattle. (2005) What is 2045 Seattle? 2045 Seattle. Retrieved November 1, 2006, from http://2045seattle.org/?page_id=13

2045 Seattle. (2006) The Seattle monorail green line map, facts \& benefits. Retrieved February 6, 2007, from http://2045seattle.org/?page_id=94 
Table 1: Seattle Monorail Project Chronology of Events - 1997 to 2005 (excerpted from Seattle Popular Monorail Authority Board of Directors, 2005)

\begin{tabular}{|c|c|}
\hline Date & Event \\
\hline November 1997 & $\begin{array}{l}\text { Voters in Seattle approved Initiative 41, which called for the City of Seattle to create a public development authority, the Elevated Transportation Company } \\
\text { (ETC), and which also proposed a 40-mile citywide monorail system. }\end{array}$ \\
\hline \multirow[t]{2}{*}{ November 2000} & $\begin{array}{l}\text { Voters in Seattle approved Initiative } 53 \text {, which required that the ETC be reinstituted, after } \$ 200,000 \text { Public Development Authority (PDA) funding ran out. } \\
\text { The Seattle City Council repealed Initiative } 41 \text { and disbanded the ETC, and be provided with } \$ 6 \text { million and two years to develop a Monorail Plan. }\end{array}$ \\
\hline & $\begin{array}{l}\text { Pursuant to Initiative 53, the ETC developed and presented for approval by Seattle voters the ETC Seattle Popular Monorail Plan, which set forth a proposal } \\
\text { for the planning, construction, and operation of a monorail system in the city of Seattle }\end{array}$ \\
\hline 2002 & $\begin{array}{l}\text { The Washington State Legislature enacted an enabling statute, codified at } \\
\text { RCW } 35.95 \mathrm{~A} \text {, allowing voters to create a city transportation authority with the power to plan, construct, and operate a monorail system in the city of Seattle. }\end{array}$ \\
\hline November 2002 & $\begin{array}{l}\text { The Seattle Popular Monorail Authority (the "Seattle Monorail Project") was formed when the voters of Seattle approved Petition/Proposition No. 1, } \\
\text { approved a 1.4\% Motor Vehicle Excise Tax, and approved the ETC Plan, providing for construction of the Green Line as the first phase of a city-wide } \\
\text { monorail transportation system. }\end{array}$ \\
\hline $\begin{array}{l}\text { December 16, } \\
2002\end{array}$ & $\begin{array}{l}\text { The Board approved Resolution 02-03, Adoption of Seattle Popular Monorail Plan. To begin the rapid and efficient implementation of the Plan, the Board } \\
\text { determined that it was necessary and desirable to adopt a procurement approach for the design, construction, and operation of the Green Line. The Board } \\
\text { approved Resolution 02-10, Adopting Procurement Approach, which adopted the Design-Build-Operate-Maintain (DBOM) procurement approach and } \\
\text { further authorized the Executive Director or his designees to commence procurement on this general basis as soon as practicable. }\end{array}$ \\
\hline $\begin{array}{l}\text { February, } 5 \text {, } \\
2003\end{array}$ & The Board approved Resolution 03-15, Regarding Adoption of Bylaws. \\
\hline March 4, 2003 & The Executive Director issued a Request for Qualifications under the DBOM procurement approach. \\
\hline June 2003 & $\begin{array}{l}\text { After an extensive review and evaluation of the Statements of } \\
\text { Qualifications, the Executive Director determined that two DBOM teams, Cascadia Monorail Company, LLC (Cascadia) and Team Monorail, were } \\
\text { qualified to submit proposals in response to a Request for Proposals. }\end{array}$ \\
\hline \multirow[t]{3}{*}{$\begin{array}{l}\text { September 3, } \\
2003\end{array}$} & $\begin{array}{l}\text { The Board of Directors of the SMP adopted Resolution 03-59, authorizing the issuance of bond anticipation notes and their sale to the Bank of America, } \\
\text { N.A. in an initial principal amount not to exceed } \$ 70,000,000 \text {, for the purpose of providing money to finance the acquisition of property and other costs } \\
\text { associated with the Green Line. }\end{array}$ \\
\hline & $\begin{array}{l}\text { The Seattle Monorail Project issued its Motor Vehicle Excise Tax Bond Anticipation Note, 2003, numbered R-1 and replacement Notes numbered R-2 and } \\
\text { R-3. }\end{array}$ \\
\hline & Pursuant to RCW 35.95A.050(3)(b), the Board was required to establish criteria by which a DBOM contractor would be selected. \\
\hline $\begin{array}{l}\text { February 11, } \\
2004\end{array}$ & $\begin{array}{l}\text { The Board approved Resolution 04-09, Adopting Evaluation Criteria for Evaluating Proposals to Design-Build-Operate-Maintain the Green Line, and } \\
\text { modified these Criteria in Resolution 04-43, which was approved by the Board on July 14, 2004. The Board approved Resolution 04-10, Authorizing the } \\
\text { Executive Director to Issue a Request for Proposals, and Addenda, to Design-Build-Operate-Maintain the Green Line. }\end{array}$ \\
\hline March 3, 2004 & $\begin{array}{l}\text { Pursuant to Resolution 04-10, staff issued the Request for Proposals to design, build, operate, and maintain the Green Line and subsequently issued several } \\
\text { Addenda clarifying the Request for Proposals and establishing a due date for Proposals of August } 16,2004 \text {. Section } 8.3 \text { of the Instructions to Proposers, a } \\
\text { part of the Request for Proposals, states that Proposers meeting certain criteria shall be entitled to receive a payment for work product of } \$ 2,000,000 \text { from } \\
\text { the Seattle Monorail Project, provided that such Proposer timely executed and delivered the Payment for Work Product Agreement to the Seattle Monorail } \\
\text { Project. }\end{array}$ \\
\hline April 21, 2004 & $\begin{array}{l}\text { Cascadia and the Seattle Monorail Project executed a Payment for Work Product Agreement, in conformance with Section } 2.10 \text { of the Instructions for } \\
\text { Proposers, and as confirmed on November } 8,2004 \text { and February 10,2005, setting forth criteria for Cascadia's eligibility to receive compensation for its } \\
\text { participation in the Request for Proposals process. }\end{array}$ \\
\hline & The Seattle Monorail Project, in Section 8.4 of the Instructions to Proposers, reserved to itself all rights, which shall be exercisable by the Seattle Monorail \\
\hline
\end{tabular}




\begin{tabular}{|c|c|}
\hline & Project in its sole discretion including the right to cancel the Request for Proposals, or any part thereof. \\
\hline June 2, 2004 & The Board adopted Resolution 04-27 amending Resolution 03-59, increasing the authorized principal amount of the Note to not to more than $\$ 150,000,000$. \\
\hline \multirow{2}{*}{$\begin{array}{l}\text { August 16, } \\
2004\end{array}$} & Cascadia submitted a Proposal in response to the Request for Proposals. \\
\hline & $\begin{array}{l}\text { Staff completed a detailed and rigorous evaluation of the Cascadia Proposal compared to the evaluation criteria established by the Board in Resolutions 04- } \\
09 \text { and } 04-43 \text { and recommended that Cascadia is the vendor best qualified to design, build, operate, and maintain the Green Line pursuant to RCW } \\
35.95 \text { A.050(3)(d). }\end{array}$ \\
\hline $\begin{array}{l}\text { September 8, } \\
2004\end{array}$ & $\begin{array}{l}\text { The Board approved Resolution 04-47, Approving the Executive Director's Recommendation that Cascadia Monorail Company, LLC (Cascadia) is Best } \\
\text { Qualified to Provide DBOM Services for the Green Line, and Authorizing the Executive Director to Initiate Negotiations of DBOM Contracts. The Board } \\
\text { approved Resolution 04-52, Amending the Real Estate Property Acquisition and Relocation Policies, Procedures and Guidelines and Delegating Authority } \\
\text { Regarding Property Acquisition. }\end{array}$ \\
\hline May 4, 2005 & The Board approved Resolution 05-15, amending Resolution 03-59 and Resolution 04-27, to extend the maturity of the Note to August 31, 2006. \\
\hline June 20,2005 & $\begin{array}{l}\text { Staff presented to the Board a recommended Design-Build-Equip Contract, an Operate and Maintain Contract (collectively, the "Negotiated } \\
\text { Agreements"), and a proposed Finance Plan for its review. }\end{array}$ \\
\hline June 30,2005 & The Finance Committee indicated that it would not approve the staff-proposed Finance Plan. \\
\hline July 4, 2005 & The Chair of the Board and the Executive Director resigned. \\
\hline July 6,2005 & The Board appointed Tom Horkan, Director of Design and Construction to serve as Acting Interim Executive Director. \\
\hline \multirow[t]{4}{*}{ July 20, 2005} & $\begin{array}{l}\text { The Board approved Resolution 05- 22, Adopting a Monorail Action Plan (the "Action Plan”) to guide the Board's actions as it determines the best path for } \\
\text { the Seattle Monorail Project. }\end{array}$ \\
\hline & $\begin{array}{l}\text { The Action Plan required an analysis and review of all options, including reworking the Finance Plan and/or scope for the Negotiated Agreements, re- } \\
\text { opening the procurement process, and submitting a ballot measure to the voters. }\end{array}$ \\
\hline & $\begin{array}{l}\text { The Board selected an Independent Financial Policy Analyst, Kevin Phelps, to review and report on the Finance Plan and the MVET growth revenue } \\
\text { projections. }\end{array}$ \\
\hline & $\begin{array}{l}\text { The Board hired three independent outside experts as Technical Peer Reviewers to review the contracting strategy and the staff recommended Negotiated } \\
\text { Agreements. }\end{array}$ \\
\hline \multirow[t]{2}{*}{$\begin{array}{l}\text { August 17, } \\
2005\end{array}$} & $\begin{array}{l}\text { The Board adopted Resolution 05-25, selecting John Haley as Interim Executive Director, following a nationwide search, and authorized a contract with } \\
\text { Booz Allen Hamilton for his services. The Board approved Resolution 05-26, Regarding Board Schedule and Process for Monorail Action Plan, for working } \\
\text { thoroughly and expeditiously through the Monorail Action Plan. }\end{array}$ \\
\hline & The Seattle Monorail Project hired Frasca and Associates to assist in the development of a new Finance Plan. \\
\hline $\begin{array}{l}\text { September 7, } \\
2005\end{array}$ & $\begin{array}{l}\text { The Board's Independent Financial Policy Analyst, Kevin Phelps, presented his recommendations to the Board for an improved borrowing strategy that } \\
\text { would lead to an acceptable, reasonable finance plan. The independent Technical Peer Reviewers reported their findings to the Board, indicating that the } \\
\text { design-build contracting strategy was an appropriate strategy, that the terms and conditions of the Design Build Equip Contract are appropriate, and made } \\
\text { additional recommendations to reduce risk, reduce costs, and improve the overall system. }\end{array}$ \\
\hline $\begin{array}{l}\text { September 8, } \\
2005\end{array}$ & $\begin{array}{l}\text { The Acting Board Chair, Kristina Hill, signed Directive } 05-07 \text { clarifying that the Deputy Director and specified other Directors had the power to act in the } \\
\text { absence of the Interim Executive Director as well as to take certain actions (such as termination of personnel, actions relating to contracts, and signing of } \\
\text { invoices) that were excluded from the scope of services for the Interim Executive Director. }\end{array}$ \\
\hline $\begin{array}{l}\text { September 23, } \\
2005\end{array}$ & The Board approved Resolution 05-36A, Submitting Proposition 1 to Seattle voters. \\
\hline $\begin{array}{l}\text { October 17, } \\
2005\end{array}$ & $\begin{array}{l}\text { Kevin Scott of Frasca and Associates, presented a recommended new Finance Plan to fund the initial phase of the Green Line from Dravus Station in } \\
\text { Interbay to Alaska Junction Station in West Seattle. }\end{array}$ \\
\hline \multirow{2}{*}{$\begin{array}{l}\text { October 24, } \\
2005\end{array}$} & The Board approved Resolution 05-38, Adopting a Finance Plan for the Initial Phase of the Green Line \\
\hline & $\begin{array}{l}\text { Resolution 05-36A provided that in the event voters did not approve Proposition 1, "the Board shall terminate [the Seattle Monorail Project] as quickly as } \\
\text { practicable, consistent with maximizing the realized value of SMP assets and efficiently discharging all obligations of [the Seattle Monorail Project]." }\end{array}$ \\
\hline
\end{tabular}




\begin{tabular}{|c|c|}
\hline \multirow{5}{*}{$\begin{array}{l}\text { November 8, } \\
2005\end{array}$} & Seattle voters rejected Proposition 1 \\
\hline & The Interim Executive Director indicated his desire not to remain in that capacity if the Green Line Project would not be going forward. \\
\hline & $\begin{array}{l}\text { The Board, in order to terminate the Seattle Monorail Project as quickly and as efficiently as practicable, wished to reject the proposed Negotiated } \\
\text { Agreements and to cancel the Request for Proposals to design, build, operate, and maintain the Green Line. }\end{array}$ \\
\hline & $\begin{array}{l}\text { Cascadia was entitled to receive payment for its work product, pursuant to the terms and conditions of the Payment for Work Product Agreement signed on } \\
\text { April 21, 2004, as confirmed on November } 8,2004 \text { and February } 10,2005 \text {. }\end{array}$ \\
\hline & $\begin{array}{l}\text { The Board, consistent with its fiduciary duties, authorized staff to take the steps necessary to terminate the Seattle Monorail Project as quickly as } \\
\text { practicable. }\end{array}$ \\
\hline $\begin{array}{l}\text { November 9, } \\
2005\end{array}$ & 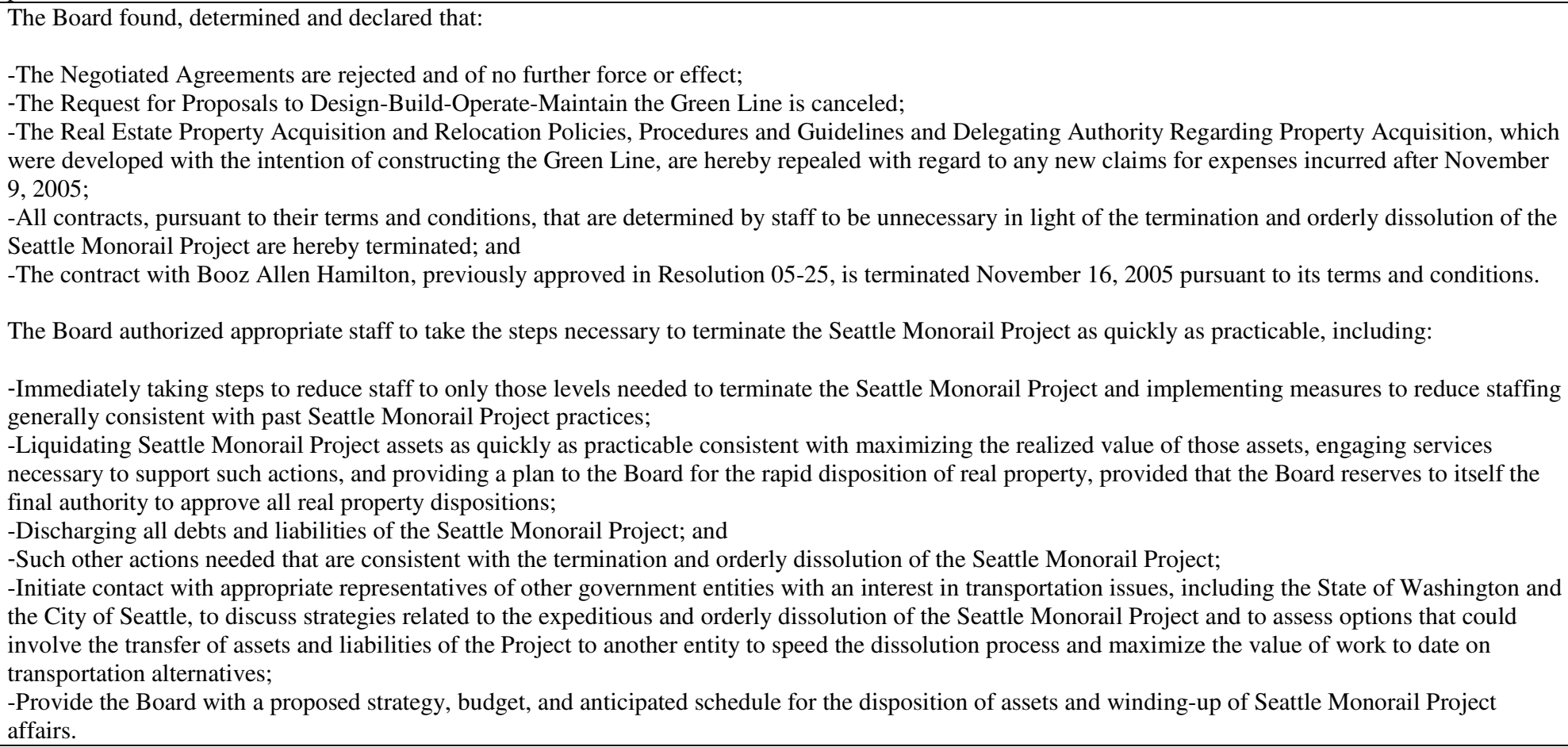 \\
\hline
\end{tabular}


Table 2: 23 Reasons for Recalling the Monorail

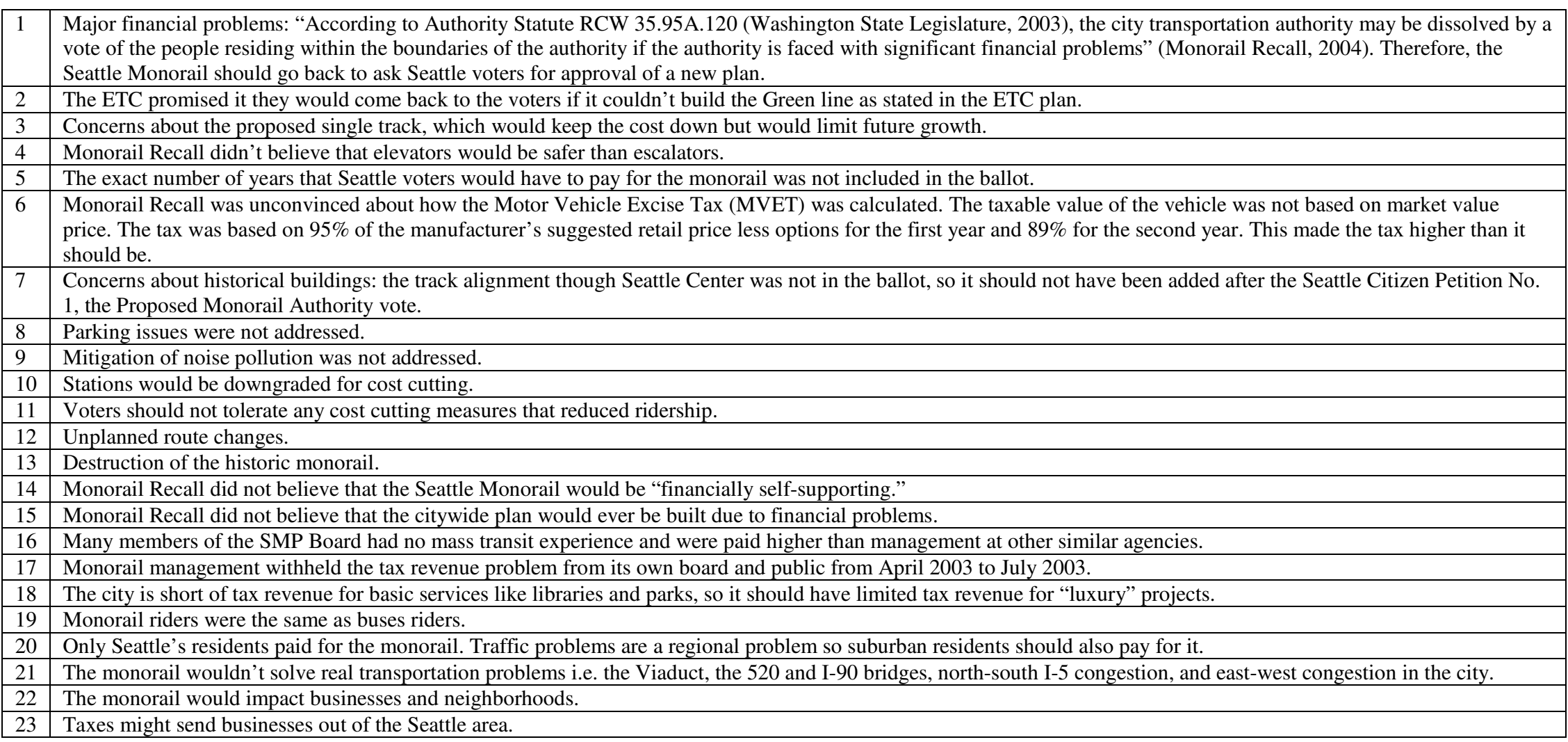

